\title{
Validação do Escore de Risco do EBMT em 1.084 pacientes portadores de leucemia mielóide crônica submetidos ao transplante alogênico de células precursoras hematopoiéticas no Brasil
} Allogeneic hematopoietic stem cell transplantation - EBMT risk score validation in 1084 chronic myeloid leukemia patients transplanted in Brazil

Milton A. Ruiz

Resumo

O estudo consistiu de análise retrospectiva de 1084 pacientes transplantados em dez Centros brasileiros, no período de fevereiro de 1983 a março de 2003, sendo o objetivo principal validar o Escore de Risco do EBMT em pacientes portadores de Leucemia Mielóide Crônica submetidos ao Transplante de Células Precursoras Hematopoiéticas.

A idade dos pacientes, fase da doença no momento do transplante, tipo de transplante, se aparentado HLA idêntico, não aparentado ou com discrepâncias no HLA, pareamento de sexos entre doador e receptor, intervalo entre a data do diagnóstico e data do transplante são os critérios que constituem o Escore de Risco do EBMT. As pontuações de cada um desses critérios e a sua somatória estratificam os pacientes em Escores de Risco de zero a sete.

A idade média dos pacientes foi de 33 anos (6-58), sendo $647(59,7 \%)$ do sexo masculino e $437(40,3 \%)$ do feminino. Encontravam-se na fase crônica de doença, no momento do transplante, $898(82,8 \%)$ pacientes; 146 $(13,5 \%)$, na fase acelerada; e $40(3,7 \%)$, na fase blástica.
Em $151(13,9 \%)$, a idade era inferior a 20 anos; em 620 $(57,2 \%)$, entre 20 a 40 anos; e $313(28,9 \%)$ tinham a idade superior a 40 anos. Em $1.025(94,6 \%)$ pacientes, o transplante foi aparentado HLA idêntico e somente em $59(5,4 \%)$ foi não aparentado. A combinação de sexos, entre paciente masculino e doador feminino, ocorreu em 283 transplantes $(26,1 \%)$, enquanto outro tipo de combinação foi observado em $801(73,9 \%)$ procedimentos. O intervalo do diagnóstico e a data do transplante foi inferior a 12 meses em $223(20,6 \%)$ pacientes e superior em 861 (79,4\%). Em $179(16,6 \%)$ pacientes, o Escore de Risco era de 0 ou 1, em $379(36,6 \%)$, o Escore foi de 2, em $345(31,8 \%)$ de 3, em 135 $(12,5 \%)$ de 4 , e, finalizando, em $28(2,6 \%)$ os pacientes estavam distribuídos entre os Escores de Risco 5 e 6 . Não houve pacientes com Escore de Risco 7.

A sobrevida global da casuística foi de $49,23 \%$, mediana de 67; a sobrevida livre de doença, 50,36\%; a mortalidade relacionada ao transplante, $45,18 \%$; e a Incidência de Recaída, 24,66\%.

Os pacientes com Escores de Risco 0, 1 e 2 em relação à sobrevida global não apresentaram diferenças $(58,5 \%$ $-55,4 \%$ e Risco Relativo 19). A sobrevida global foi significativa em relação ao Escore de Risco a partir do Escore 3 (44,3\% e Risco Relativo 53). O critério fase da doença foi considerado significativo. A fase crônica apresentou sobrevida global de 54,7\%; a fase acelerada, sobrevida global de $27,7 \%$ e risco relativo de 81 ; a fase blástica apresentou sobrevida global de $14 \%$ e risco relativo de 211 . A

Professor Adjunto Departamento de Medicina - Famerp - SJ Rio Preto-SP. Coordenador da Unidade de TMO do Hospital de Base de SJ Rio Preto-SP.

Tese apresentada para o Concurso à Livre-Docência , área do conhecimento de Medicina, Especialidade Hematologia. Faculdade de Medicina de São José do Rio Preto - Famerp. São José do Rio Preto-SP - Brasil.

Correspondência para: Milton Artur Ruiz Av. Brigadeiro Faria Lima, 5544 15090-000 - São José do Rio Preto-SP

E-mail:milruiz@terra.com.br 
combinação de sexos entre paciente e doador foi significativa, com sobrevida global de $40,5 \%$, e risco relativo de 33 quando do pareamento entre doador feminino e receptor masculino. Outras combinações apresentaram valor de $52,4 \%$. Não houve dados significativos nos outros três critérios em relação à sobrevida global.

O Escore de Risco foi significativo em relação à sobrevida livre de doença, mortalidade relacionada ao transplante a partir do Escore 3 e a incidência de recidiva a partir do Escore 5-6 com valores de 45,6\%, 48,9\% e de $73,3 \%$. Isolado, o critério fase da doença foi significativo nos três parâmetros e a combinação de sexos, somente em relação à sobrevida livre de doença e mortalidade relacionada ao transplante. Os resultados indicam que o potencial de cura global dos pacientes submetidos ao transplante é de aproximadamente $50 \%$, e o Escore de Risco do EBMT, tal como foi delineado, é uma ferramenta de decisão clínica para indicação do transplante, e que os dois critérios isolados mais importantes são a fase da doença no momento do procedimento e a combinação de sexos entre doador e receptor. Com os resultados desta casuística independente podemos afirmar que o Escore de Risco para Leucemia Mielóide Crônica do EBMT foi validado e deve fazer parte dos critérios de decisão clínica de indicação do Transplante.

\section{Abstract}

This study is a retrospective analysis of 1084 patients transplanted in ten Brazilian centers in the period from February 1983 to March 2003. The main objective was to validate the EBMT risk score in chronic myeloid leukemia patients submitted to allogeneic hematopoietic stem cell transplantation.

The risk score is based on five variables: recipient age, disease stage, donor type [HLA-identical related, matched unrelated or unmatched donor], donor-recipient gender combination, and interval from diagnosis to transplantation. The total of the points allocated to each of the different criteria stratifies the patients in risk score groups of from zero to seven.

The mean age of the evaluated patients in this study was 33 years old (from 6 to 58 years), with $647(59.7 \%$ ) male and $437(40.3 \%)$ female. At the time of transplantation, $898(82.8 \%)$ were in the chronic phase, $146(13.5 \%)$ in the accelerated phase and $40(3.7 \%)$ in the blastic phase. One hundred and fifty-one $(13.9 \%)$ of the patients were under 20 years old, $620(57.2 \%)$ between 20 and 40 years old and $313(28.9 \%)$ were older than 40 . The transplantation was HLA-identical related in $1025(94.6 \%)$ of the recipients and non-related in only $59(5.4 \%)$ of the cases. The donorrecipient gender combination was female into male in 283 $(26.1 \%)$ of the transplantations, whilst other combinations occurred in $801(73.9 \%)$ cases. The interval from diagnosis to transplantation was less than 12 months in $223(20.6 \%)$ patients and greater than 12 months in $861(79.4 \%)$. In 179 $(16.6 \%)$ patients, the risk score was 0 or 1 , in $379(36.6 \%)$ the score was 2, in $345(31.8 \%)$ it was 3, in $135(12.5 \%)$ it was 4 and in the remaining 28 cases $(2.6 \%)$ the score was 5 or 6 . There were no cases with a score of 7 .

The overall survival rate was $49.23 \%$ at a median of 67 months. The disease free survival rate was $50.36 \%$, the transplant-related death rate was $45.18 \%$ and the incidence of relapse was $24.66 \%$.

Patients with risk scores of 0 and 1 or 2 in relation to the overall survival rate did not present with significant differences (58.5\% - 55.4\%: Relative Risk 19). The overall survival rate was significant in relation to risk score of 3 and greater (44.3\%: Relative Risk 53). The criterion, disease stage, was considered significant. The chronic phase gave an overall survival rate of $54.7 \%$; the accelerated phase $27.7 \%$ (relative risk of 81 ) and the overall survival rate in the blastic phase was $14 \%$ (relative risk of 211). The donorrecipient gender combination was also significant with an overall survival rate of $40.5 \%$ (relative risk 33 ) when the transplant was female into male. Other combinations presented with a rate of $52.4 \%$. There were no significant data of overall survival in relation to the other three criteria.

The risk score was significant in respect to the disease free survival, transplant-related death with scores of 3 and higher, and incidence of relapse with scores of 5 or 6 with values of $45.6 \%, 48.9 \%$ and $73.3 \%$ respectively. In isolation, the disease phase was significant in the three parameters and donor-recipient gender combination only in relation to disease free survival and transplant-related death. The results indicate that the potential of overall cure of patients submitted to transplantation is approximately $50 \%$, and that the EBMT score as it was designed is a decision making tool for indication of transplantation. Additionally, the results identify the disease stage and the donor-recipient gender combination as the two most important independent criteria. With the results of this independent study, we can confirm that the EBMT risk score for chronic myeloid leukemia is valid and should be used for clinical decision making when indicating transplantation.

Avaliação: A Revista Brasileira de Hematologia e Hemoterapia publica os resumos e abstracts de teses da área apresentados em universidades que tenham programas de pós-graduação reconhecidos pelo MEC/CAPES e considere a obtenção do título suficiente para sua publicação na forma como se propõe a seção.

Recebido: $21 / 06 / 2004$

Aceito: $28 / 06 / 2004$ 